\title{
Patrick J. Charles, Armed in America: A History of Gun Rights from Colo- nial Militias to Concealed Carry (Amherst, NY: Prometheus Books, 2018). 555 pp. Hardcover $\$ 29.50$.
}

"To say the history of gun rights is contentious would be an understatement" (11) suggests Patrick J. Charles in the introduction of his thoughtful and meticulously researched book Armed in America: A History of Gun Rights from Colonial Militias to Concealed Carry. One might expand on Charles' comment to note that writing anything about guns in the United States is contentious - whether the subject is the effectiveness of firearms regulations, gun culture, the relationship of gun ownership to masculinity, or the history of firearm ownership and use. However, the close connection between firearms and several touchstones of American political and cultural life, such as the American Revolution, the "Founding Fathers," and the rhetoric of individual freedom, means that a historic discussion of "gun rights" is bound to attract special attention.

Charles focuses on one aspect of firearms in American history: the changing way in which Americans have conceived gun rights from before the War of Independence to the late twentieth century. He begins by examining English constitutional history to provide context to the thinking of colonial revolutionaries and drafters of the American constitution. He then explores the original meaning of that amendment, its shifting interpretation, the efforts of gun advocates to oppose or shape proposed gun controls, the creation of academic historical literature supporting the gun rights movement, and when and how courts eventually accepted that version of history. A lawyer by training, Charles is well suited to undertaking this subject. He has already published extensively on the history of gun rights, authoring The Second Amendment: The Intent and Its Interpretation by the States and the Supreme Court (Jefferson, NC: McFarland \& Company, 2009), as well as numerous law journal articles. He has also thought carefully about the judicial use of history, publishing Historicism, Originalism and the Constitution: The Use and Abuse of History in American Jurisprudence in 2014 (Jefferson, NC: McFarland \& Company).

Charles insists his exploration of the history of gun rights "adheres to accepted historical methodology and objectivity norms" (11). He claims to have pursued, read, evaluated, and employed all the available evidence in the hope of offering an "unbiased" analysis. On one hand, his claim to pursue an objective interpretation based on the evidence seems quaint and outdated. On the other hand, Charles' approach is refreshing given the politicized nature of much of the legal and historical literature on firearms in the United States.

Charles argues that gun rights rhetoric appeared in the nineteenth century, though not as early as the American Revolution, as some other scholars suggest. Charles calls efforts to construct a belief in gun rights before and during the Amer- 
ican Revolution a "pathetic fallacy" (311). He argues that the "Founding Fathers' conception of the Second Amendment had little to do with a right to own, maintain, and use firearms for hunting, shooting, and self-defense" (311). Rather, he emphasizes that the Second Amendment dealt with the militia, which to contemporaries "maintained political, societal, constitutional, and ideological significance" (311). To keep a "well-regulated" militia in the late eighteenth century required the people be armed, but not as an armed rabble and not for personal use per se, but rather as a "tool to achieve the constitutional end of republican liberty" (312).

Charles then suggests that this civic republicanism model was replaced, especially in the American south, by a view that citizens had a right to arm themselves for self-defence. In most of the United States, however, the assumption remained in place that governments could regulate the right to possess or use weapons through the police power. This resulted in a substantial flurry of gun controls in the nineteenth century. After the Civil War, the majority view across the United States became that state and local governments had the power to regulate dangerous weapons in the interest of public safety. By the early twentieth century, however, many Americans came to believe that the Second Amendment protected a right to own firearms for lawful and legitimate purposes outside of service in the militia, even though the American Supreme Court never defined the right in such broad terms. Gun rights advocacy groups, though, slowly built popular and academic support for a broad definition of the amendment, ultimately resulting in a 5-4 decision by the United States Supreme Court adopting an individual right to bear arms unencumbered by any connection to militia service.

Charles's interpretation of the Second Amendment as tied to the militia will not be met with applause by gun rights advocates. His effort to objectively examine the development of gun rights discourse means, though, that he also highlights aspects of Americans' relationship with firearms that will not please advocates of gun control either. One example of this is his view that "gun rights" were emphasized well before World War Two.

Armed in America includes a number of useful illustrations-advertisements, political cartoons, drawings and photographs—that highlight shifting attitudes about firearms and gun rights. Charles is careful to hedge some of his claims, including his assertions about the relative popularity of views among the public. At times, the text can feel encumbered by the author's effort to employ numerous examples to prove his arguments, though given that he seeks to write a definitive account of attitudes to gun rights in America this is forgivable. Some may find his criticism of other scholars harsh. For example, he takes aim at Joyce Lee Malcolm, who argues that English constitutional history supports an individual right interpretation of the Second Amendment. Charles claims that errors in Malcolm's interpretation stem from a "failure to fully adhere to accepted historical methodologies" (14). He later says Malcolm's proclamation that ownership and use of arms was virtually unregulated in England is "historical mythmaking at its finest" 
(62). He also criticizes the academic literature advocating a broad interpretation of the Second Amendment, saying these scholars "strive to compliment one another's writings by taking each other's claims at face value, building upon them, and therefore creating a self-reinforcing chain of pseudo historical scholarship" (282). He calls this work "manufactured history" (286). These are serious allegations, but Charles offers compelling evidence to support these pointed jabs.

Charles has produced a densely researched, accessibly-written study that, true to his goal, tries to offer a more objective account of how, when, and why gun rights advocates have reshaped an understanding of the place of firearms in the American legal order. It will likely not alter the views of people who have strong opinions about this subject, but Armed in America may persuade those genuinely curious about the historic place of guns in American legal thinking.

R. Blake Brown

Saint Mary's University 